\title{
HAWANA
}

A Matrix Analysis of Bontoc Case-Marking Particles

Author(s): Lawrence A. Reid

Source: Oceanic Linguistics, Vol. 3, No. 1, Papers in Philippine Linguistics (Summer, 1964), pp. 116-137

Published by: University of Hawai'i Press

Stable URL: http://www.jstor.org/stable/3622944

Accessed: 09/11/2009 01:42

Your use of the JSTOR archive indicates your acceptance of JSTOR's Terms and Conditions of Use, available at http://www.jstor.org/page/info/about/policies/terms.jsp. JSTOR's Terms and Conditions of Use provides, in part, that unless you have obtained prior permission, you may not download an entire issue of a journal or multiple copies of articles, and you may use content in the JSTOR archive only for your personal, non-commercial use.

Please contact the publisher regarding any further use of this work. Publisher contact information may be obtained at http://www.jstor.org/action/showPublisher?publisherCode=uhp.

Each copy of any part of a JSTOR transmission must contain the same copyright notice that appears on the screen or printed page of such transmission.

JSTOR is a not-for-profit service that helps scholars, researchers, and students discover, use, and build upon a wide range of content in a trusted digital archive. We use information technology and tools to increase productivity and facilitate new forms of scholarship. For more information about JSTOR, please contact support@jstor.org.

University of Hawai'i Press is collaborating with JSTOR to digitize, preserve and extend access to Oceanic Linguistics. 


\section{A MATRIX ANALYSIS OF BONTOC \\ CASE-MARKING PARTICLES}

Lawrence A. Reid

\section{Introduction}

\section{Topic-Marking Particles}

2. Referent (nontopic) Marking Particles

3. Contrastive Particle Matrices

4. Implication

0. Introduction. There is a class of particles in Central Bontoc, the members of which indicate the syntactic relationship between the substantive phrases which they introduce, and the predicate of the clause in which they occur. We call these particles case-marking particles.

The purpose of this paper is to show how the field structure of these particles as revealed by the use of matrix techniques 1 enables us to set up two contrastive sub-classes of case-marking particles--topic and referent--and to indicate the implications of this dichotomy with reference to Bontoc substantive phrases.

A listing of all case-marking particles includes six free morphemes and one clitic: nan, san, si, da, qas, qan and $\underline{-n}$, which may occur either independently, i. e. not in combination with any other case-marking particle, or dependently, i.e. in combination with either one or two other case-marking particles. The following combinations occur: nan si, sansi, nan da, san da, gas nan, qas san, qas qan, qas qan da, qan da, $\underline{\text {-n nan, }}$-n san, -n si, and $-\mathrm{nda}$.

1. Topic-Marking Particles. In many Philippine languages the topic of a clause is marked by one of two special case-marking particles depending on whether the head word of the phrase is impersonal or personal. 2 In Bontoc however, topic can be marked 
by a total of eight particles and particle combinations signaling semantic distinctions relative to the substantive phrase head word.

Contrasts between the particles and particle combinations marking topic can be seen when they occur in minimal clauses in a paradigm. These particles precede the topic of a clause, regardless of whether actor; goal, beneficiary or accessory is the topic, and irrespective of whether the topic is in the nonemphasis position post-predicate or in the emphasis position pre-predicate. In Paradigm 1 the topic-marked phrase is actor of the action indicated in the predicate. Being post-predicate the topic is nonemphatic. The predicate in each example is enclosed in parentheses.

Paradigm 1. Illustrating topic-marking particles.
1. (qinmali) nan qaso.
'The (a, some) dogs came.'
2. (qinmali) san qaso.
' The dog (you know the one) came.'
3. (qinmali)s Juan.
'John came.'
4. (qinmali) nan si Juan.
'The person, John, came.'
5. (qinmali) san si Juan.
'John (you know the one) came.'
6. (qinmali) da Juan.
'John and his companions came.'
7. (qinmali) nan da Juan.
'The people, John and companions came.'
8. (qinmali) san da Juan.
'John and companions (you know the ones) came.'

The particles nan and si have alternates phonologically defined. nan na: na occurs in normal speech before words beginning with a glottal stop (q), otherwise nan occurs. si $-\underline{s}$ : $-\mathbf{s}$ occurs as a clitic following words ending in a vowel: otherwise si occurs. 
By placing the particles into a matrix the semantic categories can be made explicit, and any areas of ambiguity which are inherent in the system are revealed. Matrix l shows the intersection of the rows (general, specific, and anaphoric) with the columns (impersonal, personal singular, and personal plural) to form the cells. The numbers in the cells of Matrix 1 correspond to the numbers of the sentences in Paradigm 1.

The general category markers, nan, si, and da are used when the speaker does not need to limit, restrict, or specify the following noun. This is either because the noun itself is general-one representing a class-- or because the context, linguistic or extralinguistic, gives sufficient identification of the noun to make specification unnecessary. Thus nan gaso can mean 'dogs', 'some dogs', 'a dog', 'the dog', or 'the dogs'.

If the speaker wishes to specify, and if the context alone would lead to ambiguity, the specific category marked is used. There is however, ambiguity between general and specific impersonal markers in Matrix 1 , and the contrast between the two categories becomes apparent only by comparison with the personal categories in this matrix and with the impersonal category of the referent matrices $(2 a, 3 a, 4 a, 5 a$, and $6 a)$, in which there are no ambiguities. ${ }^{3}$

The anaphoric category is used when the speaker wishes to identify a noun with an antecedent in his shared experience with the hearer. This may be a linguistic or extralinguistic antecedent. Full communication between speaker and hearer in this situation is dependent upon a unit of shared experience, and it is in this sense that the term anaphoric is used. 4

Matrix 1. ${ }^{5}$

Impersonal Pers. Sing. Pers. Pl.

\begin{tabular}{|c|c|c|c|c|c|c|}
\hline General & 1. & nan & 3. & si & 6. & da \\
\hline Specific & 1. & nan & 4. & nan si & 7. & nan da \\
\hline Anaphoric & 2. & $\operatorname{san}$ & 5. & $\operatorname{san} \mathrm{si}$ & 8. & $\operatorname{san} d a$ \\
\hline
\end{tabular}

The meanings of the formatives in the cells of Matrix 1 may be listed as follows: ( $U$ to be read as 'or', i. e. 'in union with', and $\Omega$ to $b \in$ read as 'with', i. e. 'intersecting with'): 


$\begin{array}{ll}\underline{\text { nan }} & =\text { Specific U (Impersonal } \Omega \text { General) } \\ \underline{\text { san }} & =\text { Anaphoric } \\ \underline{\text { si }} & =\text { Personal Singular } \\ \text { da } & =\text { Personal Plural }\end{array}$

The categories of Matrix 1 are manifested as follows (with - to be read as 'not'):

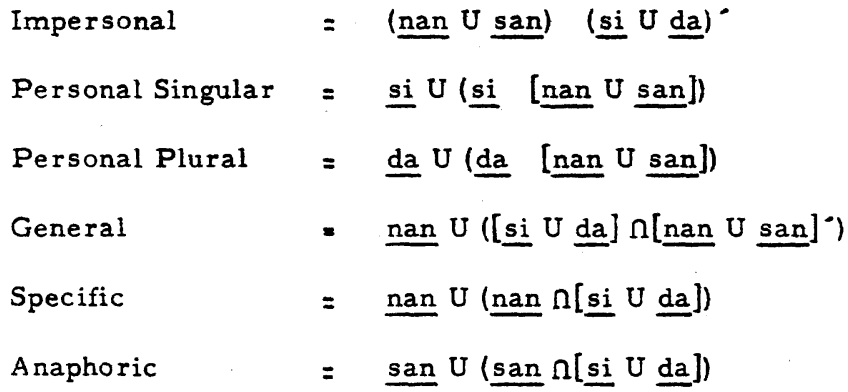

Note that the ambiguity seen in the first two cells of the impersonal column of Matrix 1 is resolved in the above listing of general and specific particles.

2. Referent (nontopic) Marking Particles. Referent substantive phrases indicate the participation of one or more additional 'dramatis personae' in the event expressed by the predicate-topic relationship. These 'dramatis personae' are: actor, goal, beneficiary, accessory, time and location. Particles which introduce referent substantive phrases reveal certain apparent ambiguities. The particle qas, for example, can precede the head word of any one of the referent phrases except referent-actor, and a phonologically defined variant of qas (si) is homophonous with a particle which can introduce a referent-actor phrase. Because of the multiple ambiguities, the particles were grouped on the basis of the external distribution of the referent phrases, to see if significant patterning of the particles would emerge. Referent actor, time and location phrases can be emphasized by pre-predicate occurrence, whereas goal, beneficiary and accessory phrases cannot 
be emphasized. 6 Of the emphasizable phrases referent-actor occurs when unemphasized immediately following the predicate and preceding the topic of a clause, whereas time and location phrases when unemphasized follow the topic of a clause.

The clauses in the following paradigm illustrate the various particles which occur with unemphasized referent-actor. The first set of parentheses in each clause enclose the predicate, the second set enclose the topic-goal. Numbers on the examples correspond to the numbers in the cells of Matrices $2 a$ and $2 b$.

Paradigm 2. Illustrating unemphasized referent-actor particles.

1. (qinala)n si qotot (nan qobi). 'Rats got the camote.'

2. (qinala)n nan qotot (nan qobi). 'The (a) rat got the camote.'

3. (qinala)n san qotot (nan qobi). 'The rat (you know the one) got the camote.'

4. (qinala)n Juan (nan qobi). 'John got the camote.'

5. (qinala)n da Juan (nan qobi). 'John and companions got the camote.'

The clitic $\underline{-n}$ has an alternate \# occurring when the predicate ends in a consonant. This set of particles indicates a possessor relationship when following a substantive head.

An attempt to place the referent particles illustrated in Paradigm 2 into a matrix of the type used for topic-marking particles left four cells empty. This lack of symmetry could not be explained by semantic appropriateness or otherwise. The system allowed for contrast between general, specific, and anaphoric only when impersonal was involved. In the personal columns, contrast is still evident between singular and plural, but no contrast is evident between general, specific and anaphoric. It seems therefore, that two matrices are required to adequately show the system in this group of particles. Matrix 2a consists of a single column vector--impersonal category--and three row vectors as in Matrix 1. Matrix $2 b$ consists of a single column vector--personal category-and two row vectors singular and plural. 
Matrix 2a.

Impersonal

General

1. $-n s i$

Specific

2. $-n$ nan

Anaphoric

3. $-n \operatorname{san}$

Matrix 2b.

Personal

Singular

4. $-n$

Plural

5. $-\mathrm{nda}$

The clauses in Paradigm 3 illustrate the particles which occur with emphasized referent-actor. The -na, and -da clitics on the predicate are concord referent-actor pronouns. Underlining in the translation indicates the emphasized phrases.

Paradigm 3. Illustrating emphasized referent-actor particles.

1. nan gotot (ginala)na (nan gobi)

'The rat got the camote.'

2. san gotot (ginala)na (nan gobi).

'The rat (you know the one), got the camote.'

3. si Juan (ginala)na (nan gobi).

'John got the camote.'

4. da Juan (qinala)da (nan gobi).

'John and his companions got

Several differences may be noted between Paradigms 2 and 3 . The clitic $-\mathrm{n}$ is absent in emphasis position (pre-predicate); the general category marker may not be emphasized; the particle which marks impersonal general when unemphasized marks personal singular when emphasized; the emphasized referent-actor phrases require the occurrence of a concord referent-actor pronoun clitic on the predicate. 
Emphasized referent-actor particles are seen in Matrices $3 a$ and $3 b$.

Matrix 3a.

General

Specific

Anaphoric

Matrix 3b.

Singular

Plural

\section{Impersonal}

nan

san

Personal

si

$\underline{\mathrm{da}}$

Formal ambiguity is found in emphasis position between referent-actor phrases, and topic phrases introduced by the particles nan, san, si, and da. This ambiguity is partially resolved on the clause level. If a referent-actor is emphasized a concord referent-actor clitic pronoun occurs on the predicate and is followed by an obligatory topic phrase or topic pronoun (example l below). If a topic-actor phrase is emphasized a concord topic clitic pronoun occurs on the predicate (example 2 below). A further differentiating criterion is the voice-marking affixation on the verb. A clause having a topic-actor always has subject voice affixation on the verb. A clause having a referent-actor always has other than subject voice affixation on the verb. If a topic phrase other than actor is emphasized (example 3 below) a concord free pronoun optionally follows the referent-actor allowing for continued ambiguity. Optional tagmemes in the examples are placed in square brackets.

1. nan gotot ginalana siya. The rat (emphasis referentactor) got-it (concord referent-actor) it (topic-goal).

'The rat got it.'

2. nan gotot ginmalada [qan siya] The rats (emphasis topic-actor) got-they (concord topic-actor) it (optional referent-goal). 'The rats got some of it.' 
3. nan qotot qinalana [siya]. 'The rat (emphasis topicgoal) got-he (referent-actor) it (optional concord topicgoal). 'He got the rat. '

The clauses in Paradigm 4 illustrate the particles introducing unemphasized time and location phrases. In Paradigm 5 the same clauses are transformed so that the time and location phrases are emphasized. Comparison of the se two paradigms and their related matrices reveals only two particle differences between emphasis and nonemphasis. The particles qas nan and qas san (impersonal specific and impersonal anaphoric) of unemphasized time and location occur as nan and san when emphasized. In the illustration topic-actor is represented by the topic pronoun clitic -ka.

Paradigm 4. Illustrating unemphasized time and location particles.

1. (qomalaka)qas Mogaw.

2. (qomalaka) qad Sakland.

3. (qomalaka) qas nan payew.

4. (qomalaka) qas san payew.

5. (qomalaka) qas qan Juan.

6. (qomalaka) qas gan da Juan.
'Get some at Mocaw.'

'Get some at Sakrang.'

'Get some from the field.'

'Get some from the field (you know the one).

'Get some from John's place.'

'Get some from the place of John and companions.'

Matrix 4a.

General

Specific

Anaphoric
Impersonal

1,2. qas $\infty$ gad

3. qas nan

4. gas san 
Matrix 4b.

$\begin{array}{ll}\text { Singular } & \text { Personal } \\ \text { Plural } & \text { gas qan } \\ \text { 6. qas gan da }\end{array}$

Paradigm 5. Illustrating emphasized time and location particles.

1. gas Mogaw (gomalaka). 'Get some at Mocaw.'

2. qad Sakland (gomalaka). 'Get some at Sakrang.'

3. nan payew (gomalaka). 'Get some from the field.'

4. san payew (gomalaka). 'Get some from the field (You know the one).'

5. qas gan Juan (gomalaka). 'Get some from John's place.'

6. qas qan da Juan (qomalaka). 'Get some from the place of John and companions.

Matrix 5a.

$\begin{array}{ll}\text { General } & \begin{array}{l}\text { Impersonal } \\ \text { Specific }\end{array} \\ \text { Anaphoric } & \text { 3. nan } \\ \text { nad }\end{array}$

Matrix 5b.

Singular

Personal

Plural

5. gas gan

6. qas gan da 
The alternates qas and qad in the upper cell of Matrices $4 a$ and $5 \mathrm{a}$ are morphologically defined: qas precedes future time words and place name subclass A (qas wakas 'tomorrow', qas tawen 'next year'; qas Datal 'to, at Chatar', gas Mogaw 'to, at Mocaw'); gad precedes past time words and place name subclass B (qad gogga 'yesterday', qad tawan 'last year'; qad Babley 'to, in the village', gad Bagiw 'to, at Faciw').

It should be noted that some time words (e.g. tawen 'year', masdem 'night') are neutral as to whether they are past or future, and may occur as either, depending upon the aspect affixation in the predicate. If the aspect is noncompletive, the time word is future and is preceded by qas. If the aspect is completive the time word is past and is preceded by qad. Some time words and place names are restricted in that they may occur only when preceded by a general category marker. Other time and place words may be preceded by either general, specific or anaphoric category markers, with interesting semantic distinctions. qas wiqit 'tomorrow morning', qas nan wiqit 'in the morning (of a certain day)', qas san wigit 'this morning (when we have just experienced)', qas Bilig 'at Mountain', qas nan bilig 'in the mountain (a particular one)', qas san bilig 'in the mountain (you know the one I mean)'.

Both gas and qad have phonologically defined alternates. qas $=$ qas $\sim \underline{-s \sim s i}$. qad $=$ qad $\underline{\text { d. }}$ qas occurs in deliberate speech or following silence. qad occurs in deliberate speech, following silence, or in normal speech following a word ending in a consonant. -s and $-\mathrm{d}$ occur in normal speech as clitics on words ending in vowels. si occurs in normal speech following a word ending in a consonant. The morphophonemic symbol QAS will be used from now on to refer to all the alternates which may occur in the top cell of Matrices $4 a$ and 5a. QAS $=($ qas $\sim \underline{-s \sim s i)} \infty$ (qad $\sim \underline{-d}$ ).

The ambiguity noted on p. 122 between emphasized topicphrases and emphasized referent-actor phrases is compounded by the occurrence of emphasized time and location phrases when the particles nan or san are involved. Note the following examples:

1. nan kababalloda pinaltoganda daida. 'The youth-their (emphasis referent-time) shot-they (concord referentactor) them (topic-goal). 'In their youth they shot them.'

2. nan baballo pinaltoganda daida. The youths (emphasis referent-actor) shot-they (concord referent-actor) them 
(topic-goal). 'The youths shot them.' nan baballo pinaltoganda daida. The youths (emphasis topic-goal) shot-they (referent-actor) them (optional concord topicgoal). 'They shot the youths.' The semantic content of the headword of an emphasized time or location phrase is usually sufficient to resolve the formal ambiguity between these phrases and other emphasized phrases.

The clauses of Paradigm 6 illustrate particles which mark unemphasizable referent phrases, i.e. goal, beneficiary and accessory. The same particles appear in Matrices $6 \mathrm{a}$ and $6 \mathrm{~b}$.

Paradigm 6. Illustrating unemphasizable referent phrases.

1. (qomalaka) qas kapi.

2. (qomalaka) qas nan kapi.

3. (qomalaka) qas san kapi.

4. (qomalaka) qan Juan.

5. (qomalaka) qan da Juan.
'Get-you (topic-actor) some coffee.'

'Get some of the coffee.'

'Get some of the coffee (you know which I mean).'

'Get some from John.'

'Get some from John and companions.'

Matrix 6a.

$\begin{array}{ll}\text { General } & \begin{array}{l}\text { Impersonal } \\ \text { Specific }\end{array} \\ \text { Anaphoric } & \text { 2, qas nan } \\ \text { An qas san }\end{array}$

Matrix 6b.

Singular

Personal

Plural

4. qan

5. gan da 
3. Contrastive Particle Matrices. Each of the matrix pairs presented in Section II covers a single field, e. g. Matrices $2 a$ and $2 b$ cover the field of unemphasized referent-actor particles, whereas Matrices $3 a$ and $3 b$ cover the field of emphasized referentactor particles. Two matrices have been required to adequately portray each field, since the field is split, each part consisting of different intersecting categories. Each $a i r$ of matrices is a matrix set. A matrix set is defined as a group of matrices each having different intersecting categories, but occurring in complementary distribution within a specified field.

Two problems now arise. The first may be stated as follows, 'Are each of the matrix sets contrastive with every other set, or may some be considered as conditioned variants of a single matrix set?' The second problem is, 'What is the relationship of the referent matrix sets to the matrix of topic-marking particles seen in Section I?'

With reference to contrastive versus noncontrastive matrices, Pike $^{7}$ states, 'we have no algorithm for determining whether two matrices are the same or different, ' but he gives certain guiding criteria, '... similarity and simplicity of description of the total system...' Specifically he states, 'In a conditioned variant of a matrix some element from outside the matrix causes the change.' He also states that it is possible to have 'variants conditioned by occurrence in different tagmemic slots,' and implies that conditioned variants of matrices should have topological identity i. e, point by point they should have the same internal patterning in spite of differences of formatives.

Conflations (superimpositions) of the formative blocks of Matrices $2 \mathrm{a}, 2 \mathrm{~b}, 3 \mathrm{a}$ and $3 \mathrm{~b}$ are now given. Hyphens mark the intersection of row and column vectors. Where there is a succession of included blocks, the formative on the left should be read preceding the formative on the right. 
Conflated Matrix Set 2. Field structure of unemphasized referentactor particles.

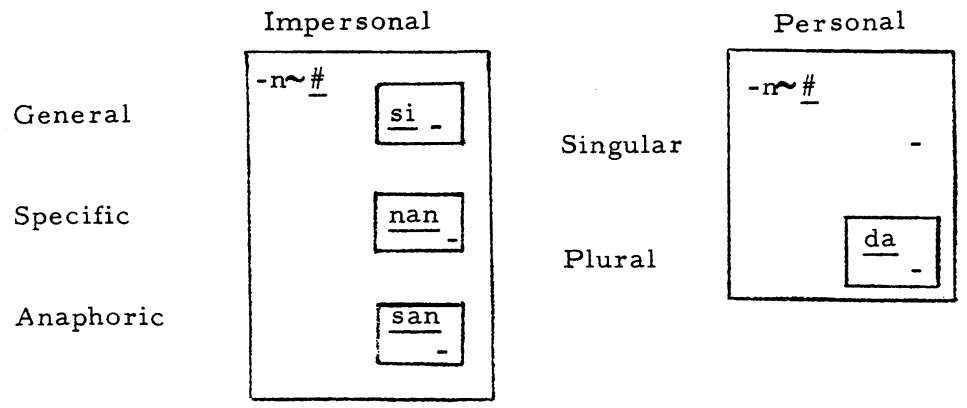

Conflated Matrix Set 3. Field structure of emphasized referentactor particles.

$$
\text { Impersonal }
$$

Specific

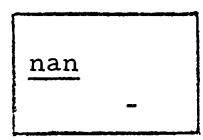

Singular

Plural
Personal

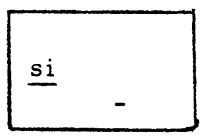

$\underline{\text { da }}$

Anaphoric

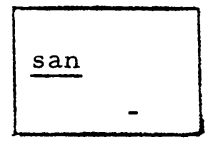

Plural

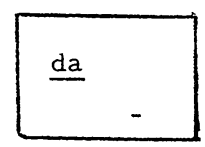

Although there is not complete topological identity of Matrix Sets 2 and 3, (because of the absence of the general category in $3 a$ and the presence of an $-n$ block covering the whole of Matrices $2 a$ and $2 b$ ) yet the two sets conflate nearly into a single set. There is moreover, a single conditioning factor to account for the differences between the matrices--the factor of emphasis versus nonemphasis. Matrix Set 7 is a combined conflation of Sets 2 and 3. Solid lines enclose Set 2 variants, dotted lines enclose Set 3 variants. 
Conflated Matrix Set $7,(=$ Set $2 \sim \operatorname{Set} 3)$. Field structure of referentactor particles.

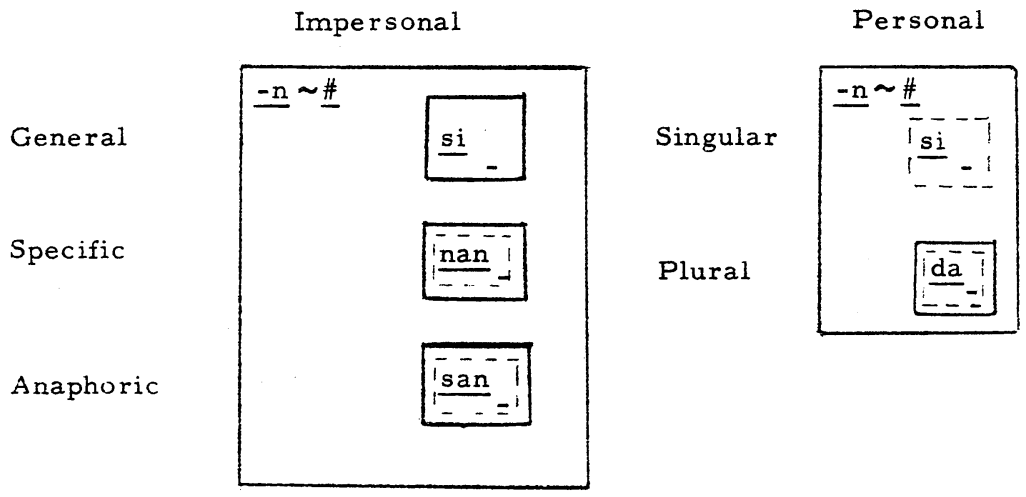

The meaning of the formatives of Matrix Set 7 may not be stated:

$\begin{array}{lll}\underline{-n \sim \#} & = & \begin{array}{l}\text { Referent-actor } \\ \text { si }\end{array} \\ \text { nan } & = & \begin{array}{l}\text { Impersonal } \cap \text { General, Personal } \Omega \\ \text { Singular }\end{array} \\ \text { san } & = & \text { Impersonal } \cap \text { Specific } \\ \text { da } & = & \text { Personal } \cap \text { Plural }\end{array}$

Referent-actor, although not a vector of a matrix is the meaning of the field covered by both matrices, and since the alternate formatives $\underline{-n}$ and \# cover the whole field they are assigned the meaning of the field. 
The categories of Matrix Set 7 are manifested as follows:

\begin{tabular}{|c|c|c|}
\hline Impersonal & $=$ & $(\underline{-n} \sim \#) \cap($ si U $\operatorname{nan} U \underline{s a n})$ \\
\hline General & $=$ & $(\underline{-n} \sim \#) \cap \underline{s i}$ \\
\hline Specific & $=$ & $(\underline{-n} \sim \#) \cap$ nan \\
\hline Anaphoric & $=$ & $(\underline{-n} \sim \#) \cap \underline{\operatorname{san}}$ \\
\hline Personal & $=$ & $(\underline{-n} \sim \underline{\#}) \cap(\underline{s i} U \underline{d a})$ \\
\hline Singular & $=$ & $(\underline{-n} \sim \underline{\#)} \cap \underline{s i}$ \\
\hline Plural & $=$ & $(-\mathrm{n} \sim \#) \cap \mathrm{da}$ \\
\hline
\end{tabular}

The ambiguities implied in the above listing between impersonal and personal, and general and singular are more apparent than real, since si only manifests the personal category when in emphasis position, and the general category never occurs emphasized (see Matrix Sets 2 and 3).

Conflation of Matrix Sets 4 and 5, show complete topological identity, and may be considered as variants of a single matrix set conditioned by the factor of emphasis versus nonemphasis. Matrix Set 8 is a combined conflation of Matrix Sets 4 and 5 .

Conflated Matrix Set 8 (= Set $4 \sim$ Set 5 ). Field structure of referent time and location particles.

Impersonal

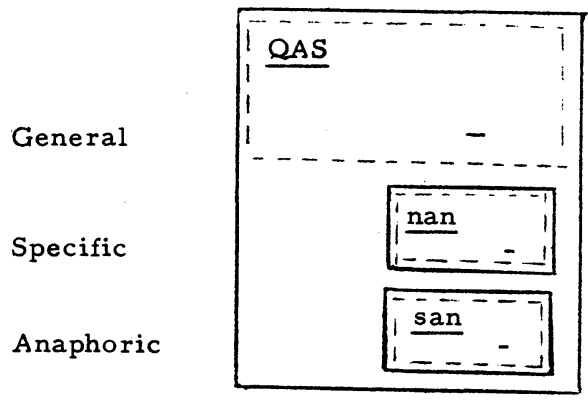

Personal

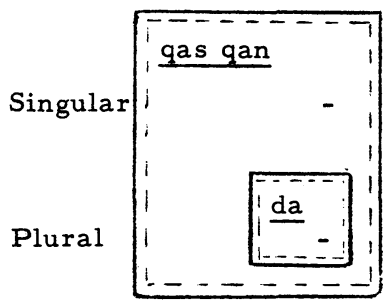


The meaning of the formatives of Matrix Set 8 are:

$\begin{array}{lll}\text { QAS } & = & \text { Impersonal } \cap \text { General } \\ \underline{\text { nan }} & = & \text { Specific } \\ \underline{\text { san }} & = & \text { Anaphoric } \\ \text { qas qan } & = & \text { Personal } \cap \text { Singular } \\ \text { da } & = & \text { Plural }\end{array}$

The categories are manifested as follows:

$\begin{array}{ll}\text { Impersonal } & =\text { QAS } \cap \text { (QAS U [nan } \cap \text { san] }) \\ \text { General } & =\text { QAS U (nan } \cap \text { san) } \\ \text { Specific } & =\underline{\text { QAS } U \text { nan }} \\ \text { Anaphoric } & =\text { QAS } U \text { san } \\ \text { Personal } & =\text { qas qan } \cap \text { (qas qan } U \text { da) } \\ \text { Singular } & =\text { qas qan } U \text { da } \\ \text { Plural } & =\text { qas qan } U \text { da }\end{array}$

Using the same procedures it is possible to treat Matrix Sets 7 and 8 as conditioned variants, and unite them into a single contrastive matrix having the field structure of emphasizable referent-marking particles. Occurrence of the variants in different tagmemic slots is the conditioning factor. A further step tests the matrix set of emphasizable referent-marking particles (i.e. a conflation of Matrix Sets 7 and 8 ) and the matrix set of unemphasizable referent-marking particles (Matrix Set 6) to see if these may also be treated as variants. Difference in tagmemic slot as the conditioning feature, correlated with topological identity of the matrices enables us to set up Matrix Set 9, a composite conflation of all referent-marking particles. For ease of reading, blocks of different variant formatives will not be separately marked where they completely overlap with one another. A single block will be marked with the alternate formatives listed within. 
Conflated Matrix Set 9 ( = Set 2 Set $4 \sim$ Set $4 \sim$ Set $5 \sim$ Set 6 ). Field structure of referent-marking particles.

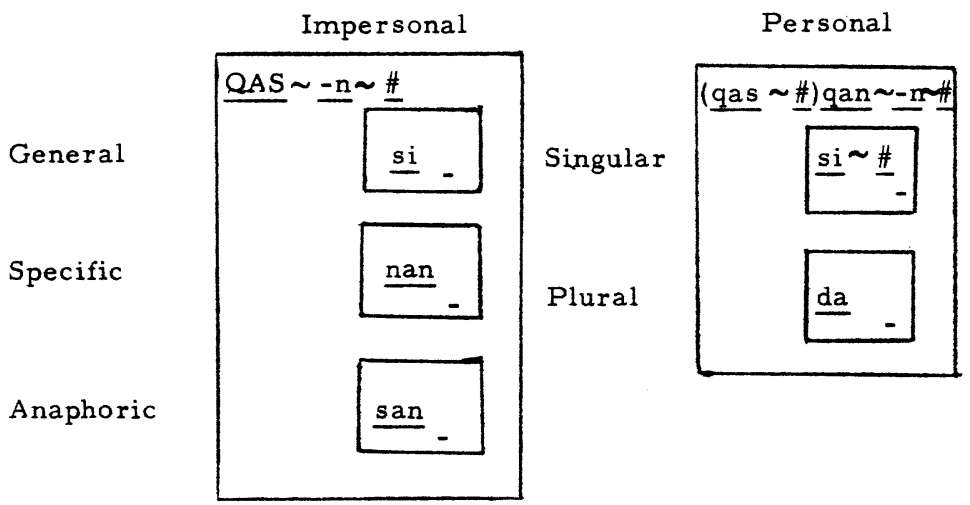

The meanings of the formatives in the cells of the conflated referent matrices of Set 9 are:

\begin{tabular}{|c|c|c|}
\hline$\underline{\mathrm{QAS}} \sim \quad \underline{-\mathrm{n}} \sim \#$ & $=$ & Impersonal \\
\hline si & $=$ & General \\
\hline nan & $=$ & Specific \\
\hline$\underline{\operatorname{san}}$ & $=$ & Anaphoric \\
\hline (gas $\sim \#$ ) gan $\sim-\mathrm{n} \sim \#$ & $=$ & Personal \\
\hline$\underline{s i} \sim \#$ & $=$ & Singular \\
\hline$\underline{\mathrm{da}}$ & $=$ & Plural \\
\hline
\end{tabular}


The categories of Matrix Set 9 are manifested by the following formatives:

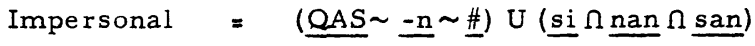

$$
\begin{aligned}
& \text { General } \quad=(\underline{Q A S} \sim \underline{-n} \sim \#) U \underline{\text { si }}
\end{aligned}
$$

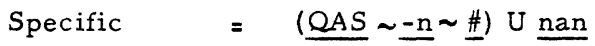

$$
\begin{aligned}
& \text { Anaphoric } \quad=\quad(\underline{Q A S} \sim \underline{-n} \sim \#) U \underline{\operatorname{san}} \\
& \text { Personal }=([\underline{q a s} \sim \text { \# }] \underline{q a n} \sim \underline{-n} \sim \text { \#) U }([\underline{s i} \sim \text { \# }] \text { A da }) \\
& \text { Singular }=([\underline{q a s} \sim \underline{\#}] \underline{q a n} \sim \underline{\underline{-n}} \sim \underline{\#}) \mathrm{U}(\underline{\mathrm{si}} \sim \underline{\#})
\end{aligned}
$$

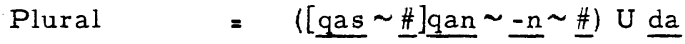

The second problem which was raised at the beginning of this section may now be considered. What is the relationship of the referent matrix sets to the matrix of topic-marking particles seen in Matrix 1?

In order to compare the field structure of topic-marking particles with the field structure of referent-marking particles (Conflated Matrix Set 9) a conflation of the formative blocks of Matrix 1 is made. This is seen in Conflated Matrix 10.

Conflated Matrix 10. Field structure of topic-marking particles.

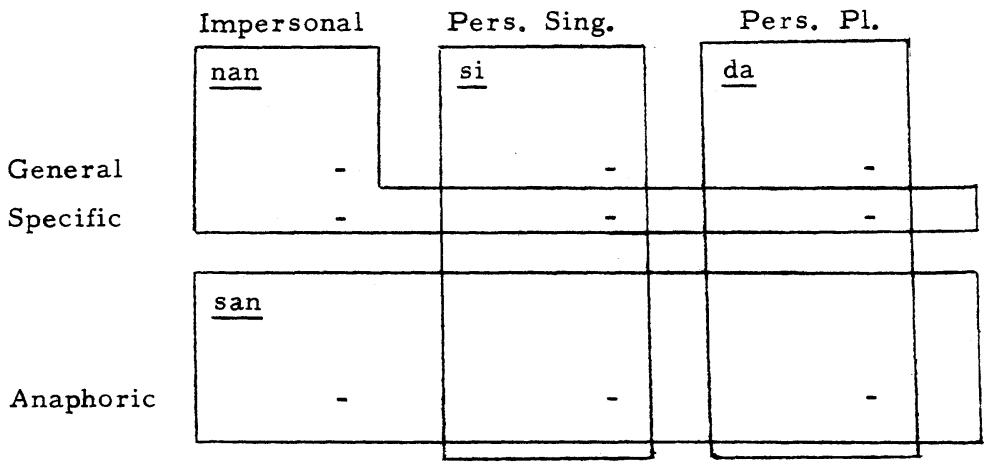


Comparison of Conflated Matrix Set 9 with Conflated Matrix 10 shows that the two field structures are not topologically the same, since Matrix 9 is a set and Matrix 10 is a single matrix. Any attempt to consider the two as conditioned variants leads to considerable difficulty of description, and so the field of topic-marking particles is considered contrastive with the field of referent-marking particles. This contrast reflects a basic dichotomy in the class of case-marking particles which may be further illustrated by using a tree diagram of the case-marking particle categories.

\section{Tree Diagram of Case-Marking Particle Categories.}

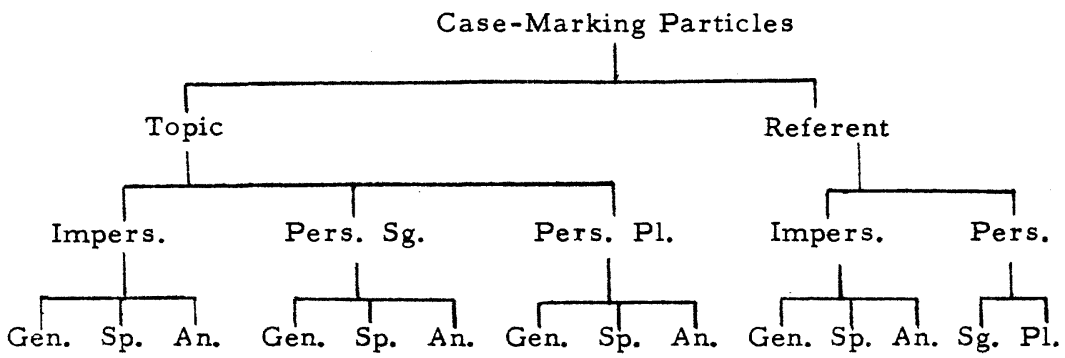

4. Implication. A question arises, 'What significance does the basic dichotomy of particle markers have in the analysis of Central Bontoc phrases?' The implication is that the class of phrases which the particles mark is also binary in character paralleling the binary division of the case-marking particle class. Other contrasting criteria which also indicate this dichotomy are difference in function, position, status and transform potential. This binary division is the first of a series of divisions which can be made within the class of case-marked phrases. Referent-case phrases for example, form a single contrastive matrix reflected in the conflated matrix of their marking particles (Conflated Matrix Set 9).

However, considered with reference to their occurrence in tagmemic slots we can distinguish three contrastively separate sets of referent phrases: referent-actor phrases with allomorphic variants in emphasis position, (Paradigms 2 and 3); referent time and location phrases with allomorphic variants in emphasis position (Paradigms 
4 and 5); and referent goal, accessory and beneficiary phrases with no allomorphic variants (Paradigm 6).

Referent time and location phrases, may be divided on the basis of difference of stem class occurrence in the head slot correlated with difference in transform potential--location phrases can be transformed to become topic of a clause, whereas time phrases cannot be so transformed. Referent goal, accessory, and beneficiary phrases may be divided on the basis of difference in verb affixation when each is transformed to topic, correlated with differences in their co-occurring verb-stem classes.

The subclass of topic-case phrases may be divided into two contrastive sets, topic-actor phrases and non-topic-actor phrases, established on the basis of difference in pronoun set substitution for each set, difference in clause structure when emphasized and difference in position of occurrence within a clause. Non-topicactor phrases may be subdivided into contrastive goal-topic, accessory-topic, beneficiary-topic and location-topic phrases on the basis of difference in verbal affixation correlated with differences in their co-occurring verb-stem classes. 


\section{NOTES}

1. Pike, Kenneth L. "Matrix Permutation and Conflation" presented under the title, "Matrix Rotation and Matrix as an Emic Unit, " to the annual meeting of the Linguistic Society of America in New York, December 29, 1962.

2. cf Elmer Wolfenden, "A Restatement of Tagalog Grammar" Manila 1961 p. 5 section 3. 1. , and Howard McKaughan, "The Inflection and Syntax of Maranao Verbs" Manila 1958 p. 11 section 2. 12 .

3. In Western Bontoc the particle di is used in some restricted situations to indicate a general impersonal noun in topic case e. g. aditako bokodan di gawis 'Let us not monopolize the good' (Motto of St. Mary's High School, Sagada, Bontoc). In most contexts however, nan is preferred. Western Bontoc di is also used to indicate a general impersonal noun in referent case corresponding to Central Bontoc si (see Conflated Matrix Set 9, p. 21). Data from Western Bontoc is from William Henry Scott.

4. William Henry Scott in his "Articles in Sagada Igorot" (in press, journal of the Association for Language Teaching), describes the case-marking particles of a language closely related to Central Bontoc; Sagada Igorot is a dialect of Western Bontoc. He divides the particles into focused and unfocused categories. His 'focus' corresponds to both my specific and to my anaphoric categories. He also notes that san indicates prior reference, including it in his focus category.

5. The particles in Matrices $1-6 b$ of this paper are abstracted from the paradigms with the corresponding numbers. Thus Matrix 1 particles are abstracted from Paradigm 1 , Matrices $2 a$ and $2 b$ are from Paradigm 2 and so on. 
6. Substantive phrases in Bontoc can only be emphasized by pre-predicate occurrence and never by emphasis particles as in some other Philippine languages.

7. Pike, Kenneth L. ibid, Section II D. 